\title{
Sofrimento e sentido no mundo contemporâneo Um diálogo entre o Homo Patiens, de Viktor Frankl e a Carta Apostólica Salvifici Doloris, de João Paulo II
}

\author{
Orientadora: Lúcia Pedrosa de Pádua \\ Mestranda: Josefa Alves dos Santos \\ Área de Concentração: Teologia Sistemático-Pastoral \\ Linha de Pesquisa: Religião e Modernidade
}

A presente dissertação tem como objetivo interrogar sobre o problema do sofrimento e do sentido de vida no mundo contemporâneo, partindo de uma análise que contextualiza a compreensão e a vivência do sofrimento na atual sociedade. Estudaremos o livro Homo Patiens, do psiquiatra vienense Viktor E. Frankl, e a Carta Apostólica Salvifici Doloris, do Papa João Paulo II, buscando, através dos pontos em comum no pensamento dos dois autores, realizar um diálogo entre fé e cultura. Diante das propostas que a sociedade contemporânea apresenta para suprimir o sofrimento e que, muitas vezes, resulta em vazio existencial, desprezo dos mais fracos e em distanciamento de Deus, buscaremos respostas mais adequadas sobre o sentido do sofrimento, sobre o valor da pessoa humana e sobre a relação entre Deus e o sofrimento humano.

Palavras-chave: Sofrimento. Sentido. Logoterapia. 